\title{
RELATIONSHIP OF EL NINO/SOUTHERN OSCILLATION TO RAINFALL PATTERNS IN NIGERIA
}

\author{
${ }^{* 1}$ Umar, A. T. and ${ }^{2}$ Kehinde, M. O. \\ ${ }^{1,2}$ Department of Geography, Usmanu Danfodiyo University, Sokoto, Nigeria. \\ *Phone: +2348070782425*Email: muskad2008@yahoo.com
}

\begin{abstract}
This paper examines the relationship between El Nino/Southern Oscillation (ENSO) and rainfall patterns in Nigeria. Annual rainfall totals, growing season rainfall totals and annual raindays of 27 Nigerian meteorological stations with varying lengths of records from 1903 to 2012 were collected from the Nigerian Meteorological Agency (NIMET). Monthly Sea Surface Temperatures (SSTs) anomalies data over Atlantic and Pacific Oceans and Southern Oscillation Index (SOI) were obtained from Climatic Prediction Centre (CPC). Kendall tau statistics and StepWise Multiple Regression model were used for data analyses. Results from this study showed that annual rainfall totals, growing season rainfall and annual raindays series exhibited a significant downward trend at most of the stations over the period of the study. It was observed that annual rainfall pattern changed from a positive pattern within 1931- 1960 period to a negative pattern within 1961-1990 period and then, to a positive pattern within 1991-2012 period. It was concluded that he alternating wet and dry patterns in inter-annual rainfall fluctuations and by extension, the droughts and floods over Nigeria within the study period, were caused by sea surface temperature anomalies over the Atlantic and Pacific Oceans. The paper therefore concludes that SSTs should be integrated in the seasonal rainfall prediction models in Nigeria for an improved forecast.
\end{abstract}

Keywords: drought, models, Nigeria, rainfall pattern, regression, sea surface temperatures

LICENSE: This work by Open Journals Nigeria is licensed and published under the Creative Commons Attribution License 4.0 International License, which permits unrestricted use, distribution, and reproduction in any medium, provided this article is duly cited.

COPYRIGHT: The Author(s) completely retain the copyright of this published article.

OPEN ACCESS: The Author(s) approves that this article remains permanently online in the open access (OA) mode.

QA: This Article is published in line with "COPE (Committee on Publication Ethics) and PIE (Publication Integrity \& Ethics)". 


\section{INTRODUCTION}

The term El Nino was coined more than 100 years ago to describe the unusually warm waters that would occasionally

form along the coast of Peru and Equador. This phenomenon typically occurs late in the calendar year towards Christmas, hence the name El Nino (Spanish word for "the boy child" referring to the "Christ child") (Mohit, 2014). Today, the term El Nino is used for a more broader scale phenomenon associated with unusually warm waters that occasionally form across much of the tropical eastern and central Pacific (Ayoade, 2011). Similarly, El Niño southern oscillation (ENSO) is a fluctuation of the ocean-atmospheric system that originates in the tropical Pacific. The warm phase is known as El Niño while the cold phase is referred to as La Niña. ENSO is one of the important sources of annual global climate variability. El Niño and its counterpart La Niña are associated with characteristic patterns of rainfall and temperature, which may include extreme events such as drought and flooding (WHO, 2015). Pidwirny (2006) states that the ocean surface cools and warms cyclically in response to the strength of the trade winds and the changing ocean consequently alter rainfall patterns. He further stresses that El Niño occurs when warm water build up along the equator in the eastern pacific. The warm ocean surface warms the atmosphere, which makes moisture rich air to rise and develop into rainstorms.

Hamilton and Allingham (1988) reported an investigation into the chronology of El-Niño /Southern Oscillation (ENSO) events between 1531 and 1841 in Peru. They identified aspects of the global teleconnections patterns usually associated with the tropical ENSO events. Van loom and Madden (1981) described the global correlations between a measure of Southern Oscillation, sea level pressure and surface air temperature in the northern winter. They found that the most stable correlation coefficients were over India; the North Pacific Ocean, the Rocky Mountains and the Central (Western North Atlantic Ocean). The characteristics of the Southern Oscillation (SO) in the tropics and sub-tropics of the southern hemisphere have been presented by many investigators, such as: Walker and Bliss (1932), Popelewiski and Halpert (1987), Dai and Wigley (2000) to mention a few.

Since the chain of events that constitute an El-Nino or La-Nina are well organized, it provides some statistical predictability in some regions around the globe. However, even when a phase of an ENSO is established, the actual understanding of the mechanism which starts the chain of events or stops it once started remains elusive. And the prediction of the onset of El Niños by both dynamical and physical models are yet to display skill relative to a simple climatology and persistence model of ENSO onset (Landsea and Knaff, 2000). One theory for ENSO is the delayed oscillator theory (Suarez and Schopf, 1988; Battisti and Hirst, 1989) which posits an unstable atmosphere/ocean system where oceanic Rossby waves generated from previous El Niños or La Niñas act as the excitation for the next ENSO event. Other mechanisms such as monsoonal activity (Webster and Yang, 1992) and the Madden Julian Oscillation (MJO) have also been proposed as modulators of ENSO; though, such theories only lengthen the chain of causality as these phenomena are themselves even less understood than ENSO. Jin and Neelin (1993) hypothesize that the tropical pacific atmosphere/ocean system is not an unstable system waiting for triggering mechanisms but that the ENSO variability is best thought of as response of the tropical pacific system to stochastic climate noise.

Studies have demonstrated the link between rainfall patterns and ENSO in Nigeria in an attempt to establish whether there is any direct relationship between rainfall variability, extreme weather event such as drought and flood as well as other rainfall characteristics such as the onset and cessation of rainfall, length of growing season, amount of 
rainfall to mention a few. While some of these studies revealed no direct relationship between rainfall patterns and ENSO since it brings both rainfall surplus and deficit (Shehu, et al., 2016 and Nnawuike, et al., 2016) others, indicate that ENSO has direct influence on the rainfall parameters in Nigeria (Ati, et al., 2010 and Benard, 2000 cited in Shehu, et al., 2016).

During an El Nino, sea level pressure tends to be lower in the eastern Pacific and higher in the western Pacific while the reverse is true for La Nina. This see-saw in atmospheric pressure between the eastern and western tropical Pacific is called the Southern Oscillation, often abbreviated as SO. A standard measure of the Southern Oscillation is the difference in sea level pressure between Tahiti and Darwin, Australia. Since El Nino and the Southern Oscillation are related, the two terms are often combined into a single phrase, the El Nino/Southern Oscillation, abbreviated as ENSO. Often the term "ENSO Warm Phase" is used to describe El Nino and "ENSO Cold Phase" to describe La Nina (Ayoade, 2011).

Once developed, the El Nino and La Nina events typically persist for about a year and so the altered rainfall patterns associated with them typically persist for several seasons as well. This can impact significantly on people living in areas of tropical pacific since the usual precipitation patterns would be greatly disrupted by either excessively wet or dry conditions. In addition, the altered tropical rainfall patterns during El Nino and La Nina does not only affect the tropical Pacific region but areas away from the tropical Pacific as well. This may include several tropical locations and regions outside the tropics within the Northern and Southern hemispheres (Popelewiski and Halpert (1987). Studies of the Southern Oscillation (SO), the El Niño and La Niña phenomena, and their associated effects over the entire atmosphere, have assumed greater economic and social importance and have been given considerable scientific attention

in recent times. The objective of this paper is to examine the relationship of El Nino/Southern Oscillation (ENSO) to rainfall patterns in Nigeria.

\section{MATERIALS AND METHODS}

The data sets used for this study included the monthly rainfall and raindays data, monthly Sea Surface Temperatures (SSTs) anomalies data and monthly Southern Oscillation Index (SOI) data. The monthly rainfall and raindays data of 27 selected Nigerian meteorological stations with varying lengths of records over the period 1903 to 2012 were obtained from the archive of the Nigerian Meteorological Agency (NIMET). The definition of a rainy day adopted by the World Meteorological Organization (WMO) as a day with at least $0.83 \mathrm{~mm}$ of rainfall was also adopted for this study (WMO, 1971). The annual and seasonal rainfall series were derived for each of the stations based on the monthly rainfall data collected at NIMET. The distribution of the 27 selected Nigerian meteorological stations is presented in Figure 1. 


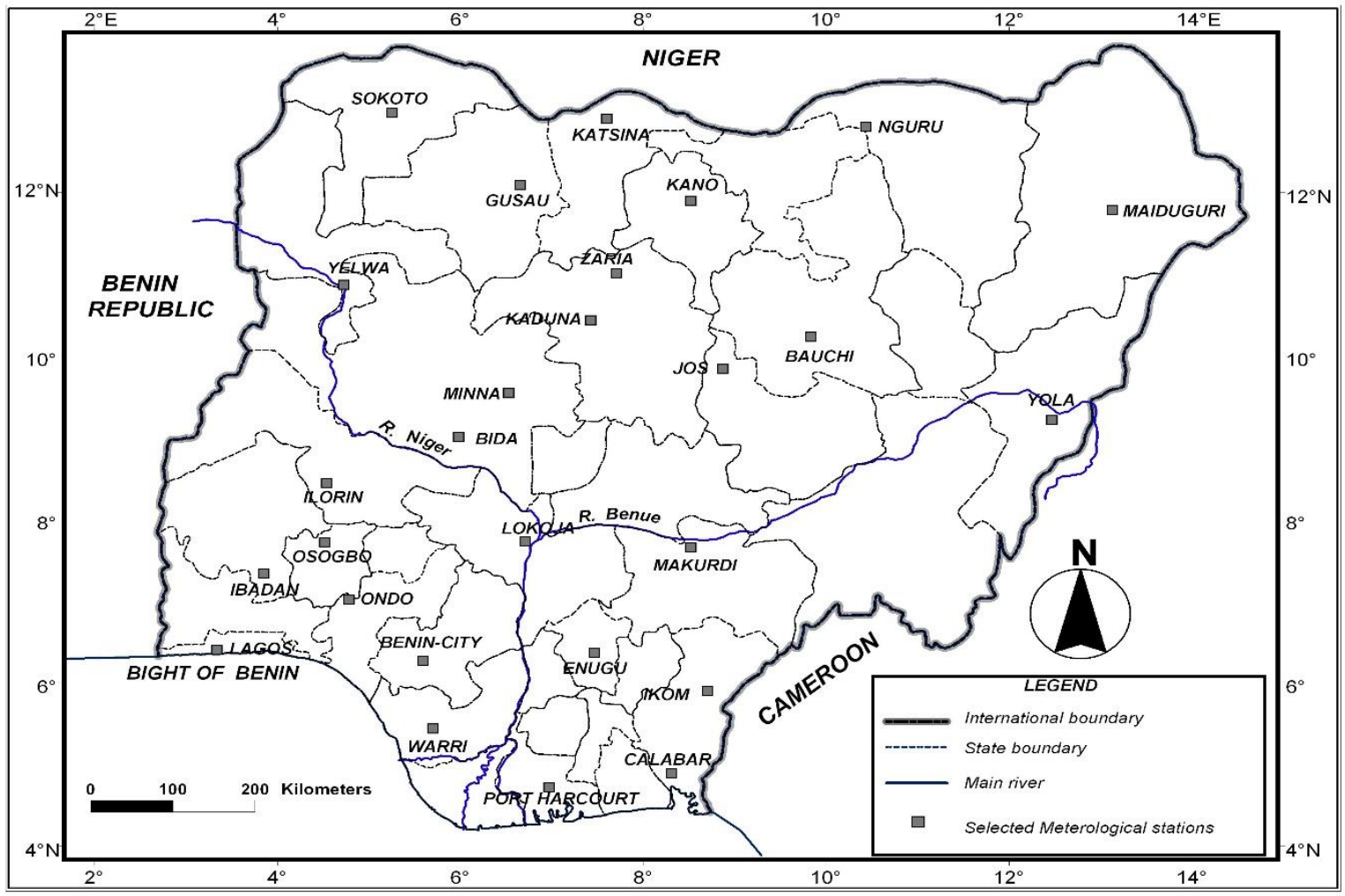

Figure 1: The Distribution of the Selected Nigerian Meteorological Stations Used for the Study

Source: Macmillan senior secondary school Atlas (2000)

Monthly SSTs anomalies of the four NINO regions for the period 1951 - 2000 were obtained from the Climatic Prediction Centre (CPC). These NINO regions are:

NINO 1+2 (Extreme Eastern Tropical Pacific) (Lat. 0-10 ${ }^{\circ}$ S, Long. $80-90^{\circ} \mathrm{W}$ ): This region typically warms first when an El-Nino event develops.

NINO 3 (Eastern Tropical Pacific) (Lat. $5^{\circ} \mathrm{S}-5^{\circ} \mathrm{N}$; Long. $150^{\circ} \mathrm{W}-90^{\circ} \mathrm{W}$ ): This region of the tropical Pacific has a large variability in sea surface temperature on El Nino time scales.

NINO 3.4 (East-Central Tropical Pacific) (Lat. $5^{0} \mathrm{~S}-5^{0} \mathrm{~N}$; Long. $170^{\circ} \mathrm{W}-120^{\circ} \mathrm{W}$ ): This region has the largest variability on El Nino time scales, being closer (than NINO 3) to the region where changes in local sea surface temperature are important for altering a larger region of rainfall typically located in the far western Pacific.

NINO 4 (Central Tropical Pacific) (Lat. $5^{0} \mathrm{~S}-5^{\circ} \mathrm{N}$; Long. $160^{\circ} \mathrm{E}-150^{\circ} \mathrm{W}$ ): This is the region where changes of sea surface temperature lead to total values around $27.5^{\circ} \mathrm{C}$, which is an important threshold in producing rainfall.

The monthly SSTs anomalies of the North Atlantic (Lat. 5-20 ${ }^{\circ}$ North, Long. 60-30 ${ }^{\circ}$ West), South Atlantic (Lat. 0$20^{\circ}$ South, Long. 30 $^{\circ}$ West- $10^{\circ}$ East) and Global Tropics (Lat. 10 ${ }^{\circ}$ South-10 ${ }^{\circ}$ North, Long. 0-360 ${ }^{\circ}$ ) for the period of 1951 - 2000 were also derived from the Climatic Prediction Centre (CPC) and used for this study. 
The monthly SOI data for the period 1951-2000 were obtained from the official web sites of Climatic Analysis Centre of the United States Department of Commerce, Washington D.C in collaboration with National Oceanic and Atmospheric Administration (NOAA), National Weather Service (NWS) and National Centre for Environmental Prediction (NCEP). Several indices have been used to quantify ENSO event; however, the most common is the southern oscillation index (SOI). It is defined as the normalized difference in monthly mean Sea Level Pressure (SLP) between Tahiti, French Polynesia (Lat. $18^{\circ} \mathrm{S}$, Long. $150^{\circ} \mathrm{W}$ ) (i.e. the Eastern Tropical Pacific) and Darwin, Australia (Lat. $12^{\circ} \mathrm{S}$, Long. $131^{0}$ E) (i.e. Western Tropical Pacific) (Chem, 1982). The SOI is calculated as Tahiti Sea Level Pressure (SLP) minus Darwin Sea Level Pressure (SLP). Negative values (i.e. anomalously low pressure in the eastern and anomalously high pressure in the western tropical Pacific) represents El Nino conditions, while positive values (i.e. anomalously high pressure in the eastern and anomalously low pressure in the western tropical Pacific) represents La Nina conditions. Several investigators have used the SOI to quantify ENSO (e.g. Fu et al., 1986; Kiladis and Diaz, 1989; Halpert and Popelewski, 1992) which this study employs. The SOI index is determined using the formula:

$$
\mathrm{SOI}=\frac{10(\text { Pdiff }- \text { Pdiffav })}{S D(\text { Pdiff })}
$$

Where:

$S O I=$ Southern Oscillation Index

Pdiff $=$ (average Tahiti mean sea level pressure for the month)-(average Darwin mean sea level pressure for the month)

Pdiffav = Long-term average of $P$ diff for the month in question

SD $($ Pdiff. $)=$ standard deviation of $P$ diff for the month in question

Multiplying the result obtained from the above formulae by 10 gives a range of values for SOI between -35 and +35 (Ayoade, 2008, 2011). Sustained negative values of SOI over months often indicate El Nino episodes and as such, negative values are usually accompanied by sustained warming of the central and eastern Tropical Pacific Ocean and a decrease in the strength of Pacific trade winds (Walker Circulation). Positive values of SOI, on the other hand, are associated with stronger Pacific trade winds and cooling of the waters of the eastern and central tropical Pacific Ocean. This episode is known as La Nina episode the opposite of El Nino. The changes in atmospheric pressure epitomized by the Southern Oscillation Index are thus related to the strength of the equatorial zonal east-west circulation. This is a zonal circulation with ascending air over Indonesia and the descending air in the east Pacific giving rise to surface easterlies and upper westerlies over most of the equatorial Pacific (See Popelewski and Halpert, 1987; Nicholson and Kim, 1997; Ayoade, 2011). The choice of 1951 - 2000 period for the monthly SSTs anomalies and the SOI was informed by the availability of the data for these variables.

The annual and seasonal rainfall data for each of the stations were analyzed for trends using the Kendall tau statistical method. The most likely alternative to randomness in a climatic time forms a trend, which may be linear or non- 
linear. It is, therefore, necessary to use a test of randomness to check the trend. The Mann-Kendall rank method was suggested as suitable test by Kendall and Stuart (1961), and hence adopted for this study.

Three sub-climatological periods between: 1931 to 1960, 1961 to 1990 and 1991-2012 were selected within the period of the study (1903 to 2012) in an attempt to depict the observed changing patterns in rainfall over Nigeria within these climatological periods. The selection of these periods was based on the results of the analysis of West African rainfall fluctuations carried out by Grist and Nicholson (2001) (Figure 2)

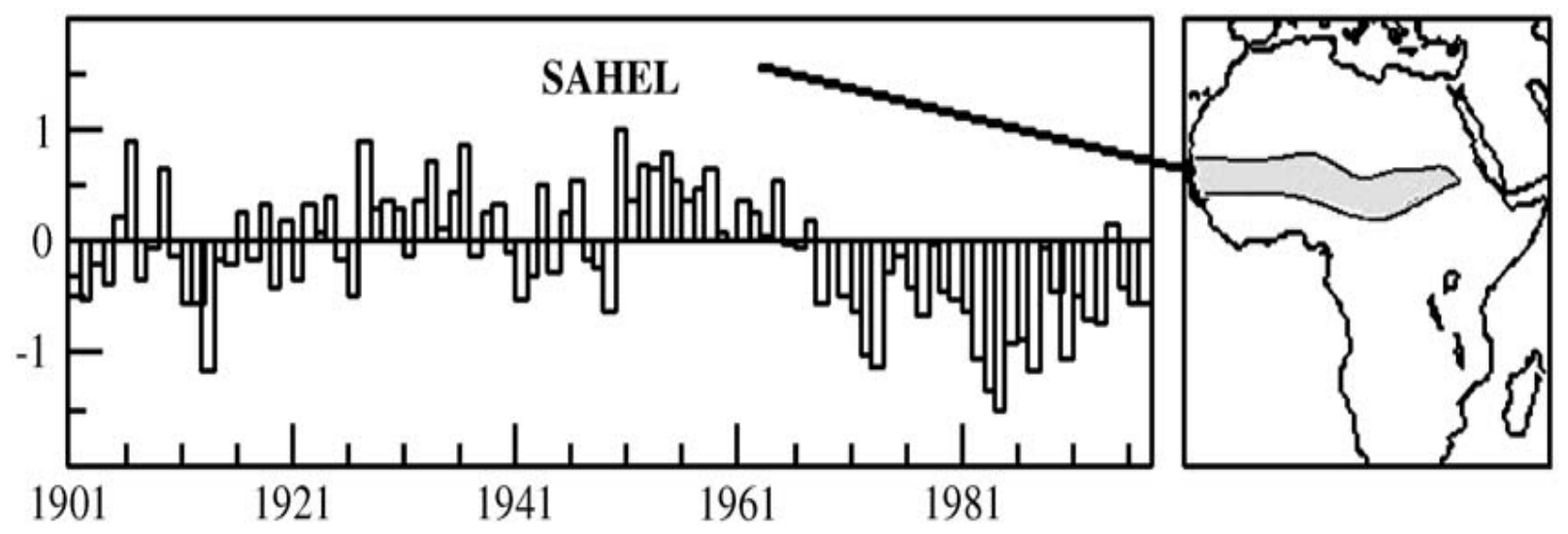

Figure 2: Rainfall Fluctuations in West Africa (1901 to 1997) Expressed as a Regionally Averaged Percent Departures from the Long-Term Mean. (After Grist and Nicholson, (2001). Location of the Region Represented is Indicated in the Inset.

Source: After Grist and Nicholson, (2001)

This analysis showed that, a marked wet period occurred in the region within 1931 to 1960 when most of the stations had their annual rainfall totals well above their long-term means. This was alternated by the continued decline in annual rainfall totals at most of the stations in the region from late 1960s to late 1980s and then followed by the appreciable rainfall recovery particularly in the West African Sahel afterwards. The apparent rainfall recovery in the West African Sahel after the droughts of 1980s in the region was equally reported by Nicholson (2005).

The mean annual rainfall for each of the stations within each of the sub-climatological periods was subtracted from the long-term mean annual rainfall for each of the stations within their respective lengths of records. The mean annual rainfall departures derived were then mapped out using the Archview version 3.3 software which displayed the observed changing patterns of rainfall in the country for each of the sub-climatological periods considered in this study. The Archview software automatically derived the mean value of the departure values provided for each of the subclimatological period and then classified the country into areas of above/below the long-term mean and mapped out the changing rainfall pattern within the three selected climatological periods for comparison.

The relationships among ENSO, SSTs anomalies and Nigerian rainfall were investigated using the step-wise multiple regression model. The most important feature of the stepwise multiple regression model is that a significant variable, which has been added at an earlier stage, may later be considered insignificant and thus deleted. At the end of the search, only the most significant variables which account for the largest portion of the total variance in the dependent variable $(y)$ that are retained in the regression equation (Ayoade, 2008). 
The independent variables used in the stepwise multiple regression models include: (1) The ENSO index, (2) Global Tropics (Lat. $\mathbf{1 0}^{\circ}$ South-10 ${ }^{\circ}$ North, Long. 0-360 ${ }^{\circ}$ ) SST anomalies (3) Niño $1+2$ (Lat. 0-10 ${ }^{\circ}$ South)(Long. $90^{\circ}$ West $-80^{\circ}$ West) SST anomalies (4) Niño 3 (Lat. $5^{\circ}$ North- $5^{\circ}$ South)(Long. $150^{\circ}$ West-90 ${ }^{\circ}$ West) SST anomalies (5) Niño 3.4 (Lat. $5^{\circ}$ North $-5^{\circ}$ South)(Long. $170-120^{\circ}$ West) SST anomalies (6) Niño 4 (Lat. $5^{\circ}$ North $-5^{\circ}$ South)(Long. $160^{\circ}$ East$150^{\circ}$ West) SST anomalies (7) South Atlantic (Lat. 0-20 ${ }^{\circ}$ South, Long. $3^{\circ}$ West-10 ${ }^{\circ}$ East) SST anomalies (8) North Atlantic (Lat. 5-20 ${ }^{\circ}$ North, Long. $\mathbf{6 0 - 3 0}^{\circ}$ West) SST anomalies. The oceanic boundaries of these regions have been demarcated by Palmer (1986) (see Figure 3).

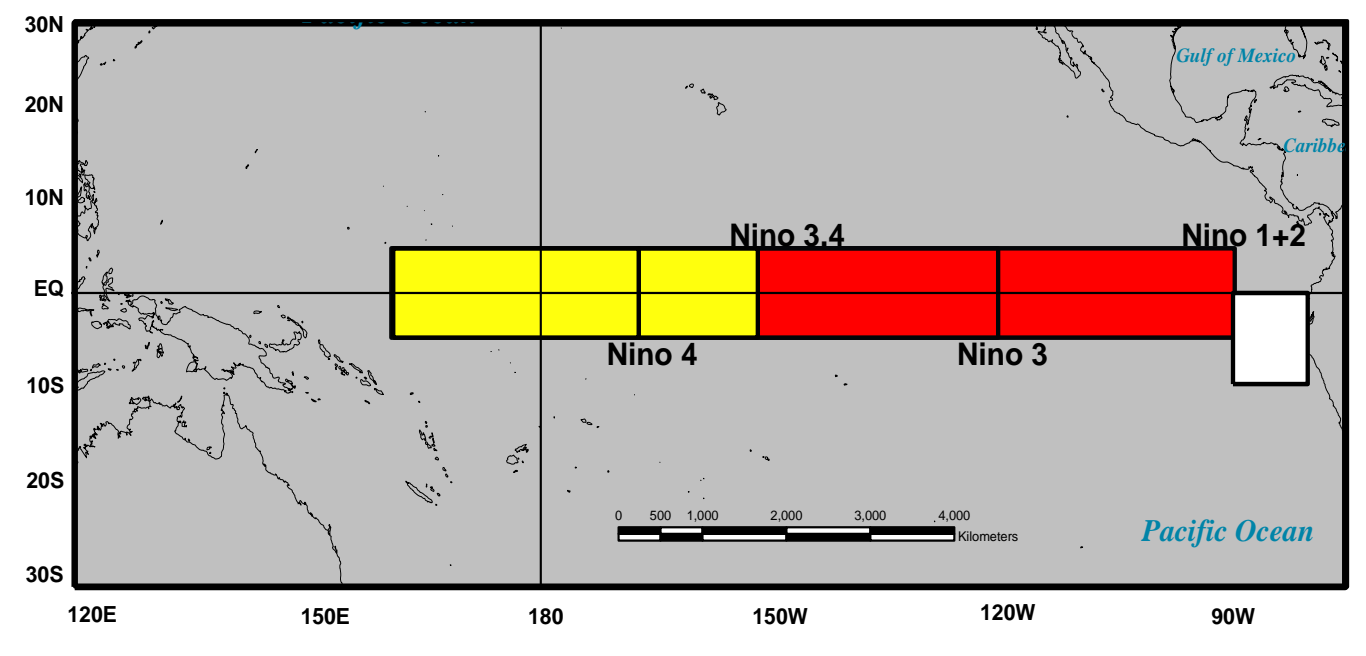

Figure 3: Graphical Depiction of the Four Niño Regions. (After, Palmer, 1986)

Source:Palmer, (1986)

The dependent variables include: Annual rainfall anomalies for the North, Annual rainfall anomalies for the Central, Annual rainfall anomalies for the South-West and Annual rainfall anomalies for the South-Eastern region. For wet season rainfall anomalies, a composite of (April +May + June) rainfall series was derived for the both the South-West and South-East regions while for the Middle belt, the Northern regions, and five selected Sudano-Sahelian stations namely; Katsina, Nguru, Maiduguri, Sokoto and Kano, a composite of (June + July + Aug) rainfall series was derived over the period from 1951 to 2000. The choice of 1951-2000 was based on the availability of data for the monthly SSTs anomalies and the monthly SOI data which all began in 1951 to 2000. These are the months during which these broad regions and Sahelian stations receive bulk of their rainfall in any given year. Direct regressions were made between the stated independent and dependent variables for the period under consideration when all 27 synoptic stations had adequate rainfall records in tandem with the records of the monthly SSTs anomalies and the monthly SOI data used to examine the relationships amongst ENSO, SSTs anomalies and the Nigerian rainfall. The seven climatic regions of Nigeria derived by Olaniran (1986) were re-grouped into four major regions based on the prevailing climatic conditions for each of the regions namely: the northern region, middle belt, south-west and south-east (see Figure 4). 


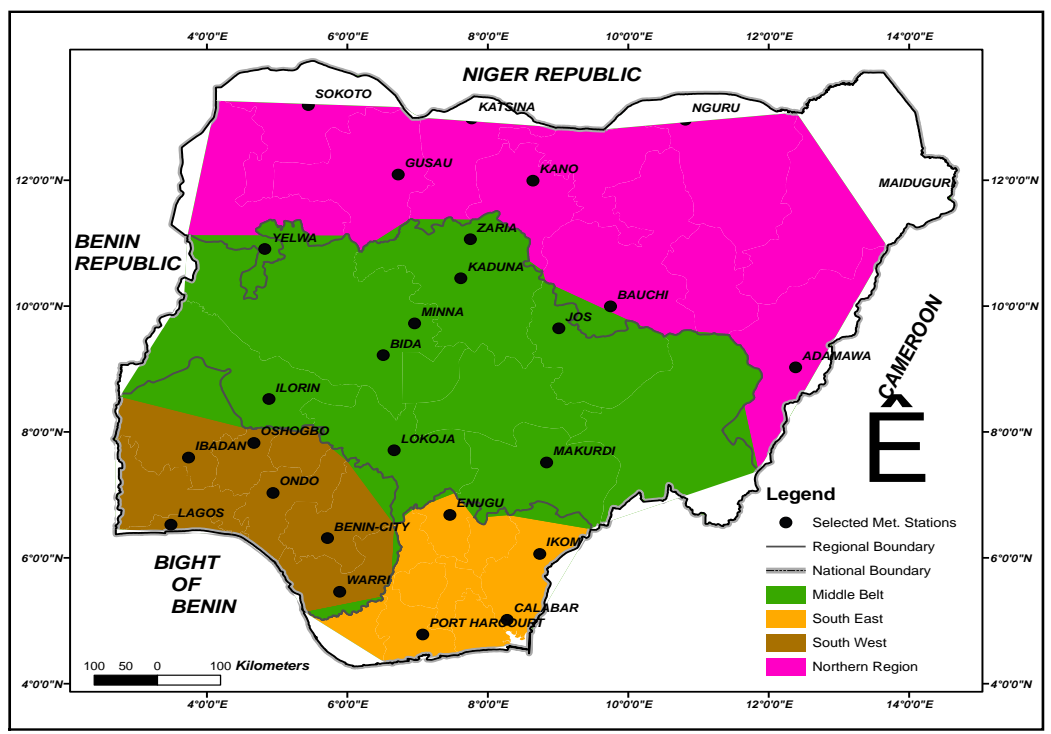

Figure 4: Re-Grouping of Olaniran's (1986) Seven Climatic Regions into four broad Regions with Stations

Source: Adapted after Olaniran’s (1986)

The Olaniran's (1986) regions (i) and (ii) which are grouped as southern region in the present study, is further divided into south-west and south-eastern regions. Hence, the country is divided into four regions which are characterized by distinct rainfall patterns. The northern region consists of nine stations which are representative of the Sudano-Sahelian zone. The middle belt region, which includes eight stations, separates the semi-arid zone of northern Nigeria from the sub-humid tropical zone of the south. The climate of the middle belt region is complicated by the topographical features of the highlands. Six stations were grouped into the south-western region which experienced double-rainfall maxima in May/June and September/October with a particularly well-marked "little dry season" in July/August (Adejuwon and Odekunle, 2006). The little dry season is associated with a temperature inversion above the surface layer which inhibits convective activity and rainfall (Adefolalu, 1986; Olaniran, 1991). Local divergence was primarily responsible for the stability in the monsoon air masses during this period. In the south-east region, which was represented by four synoptic stations, showed a tendency for somewhat less rainfall in August than during July and September; however, rainfall amounts remained considerably high throughout the entire wet season. The high rainfall amount within the south-eastern region was a common feature of the more humid equatorial zone.

\section{RESULTS AND DISCUSSION}

\section{RAINFALL TRENDS OVER NIGERIA}

It could be observed from Table 1 that annual and growing season rainfall revealed a significant upward trend at 5 of the stations in 1931-1960 period. The upward trend detected at 12 stations within the period 1931-1960 was not statistically significant and may have occurred due to chance variation. The annual and growing season rainfall revealed a significant downward trend at 12 of the stations in the period 1961-1990. The downward trend detected at the remaining 15 stations within the period 1961-1990 was not statistically significant and may have occurred due to chance variation. For the sub- 
period 1991-2012, annual rainfall totals and growing season rainfall exhibited a significant upward trend at 6 stations while the upward trend detected at the 9 stations was not significant. However, annual rainfall totals revealed a significant downward trend at 10 of the stations with most of them located in the Sudano-Sahelian region of the country. However, Ibadan, Oshogbo, Ondo and Benin stations all located in the in the more humid zone of the south revealed a significant upward trend in their annual rainfall totals within their respective lengths of records. Similar results were obtained for the growing season rainfall totals over the period 1903-2012. For annual raindays totals, 15 stations widely distributed in the country had a significant downward trend over the period 1903-2012. The trend detected at the remaining stations was not statistically significant. This conformed to the rainfall trends discussed by (Adefolalu, 1986; Anyadike, 1993). If this cyclic pattern of rainfall persists, the 2021-2050 period may witness another period of reduced rainfall in the country with its attendant consequences of severe droughts. This could lead to river dry-out and affects the natural ground water recharge and cause water crisis particularly in the rural areas of Nigeria. It could as well lead to food security challenges and hike in the price of food stuffs. 
Table 1: Annual rainfall trends over Nigeria, 1903-2012

\begin{tabular}{|c|c|c|c|c|c|c|c|c|c|c|}
\hline \multirow[t]{2}{*}{ Station } & \multirow{2}{*}{$\begin{array}{l}\text { Station } \\
\text { Record }\end{array}$} & \multirow{2}{*}{$\begin{array}{l}1931- \\
60 \\
\text { Annual }\end{array}$} & \multirow[b]{2}{*}{ Season } & \multicolumn{2}{|l|}{$1961-90$} & \multicolumn{2}{|l|}{ 1991-12 } & \multicolumn{2}{|l|}{ 1903-12 } & \multirow[b]{2}{*}{ *ARD '03- } \\
\hline & & & & Annual & Season & Annual & Season & Annual & $\begin{array}{l}\text { Season } \\
12\end{array}$ & \\
\hline Sokoto & 1916-12 & 0.15 & 0.14 & $-0.28^{*}$ & $-0.27 *$ & -0.06 & -0.06 & $-0.15^{*}$ & $-0.16^{*}$ & $-0.15^{*}$ \\
\hline Kano & $1905-12$ & -0.08 & -0.07 & $-0.26^{*}$ & $-0.26^{*}$ & $0.31 *$ & $0.31 *$ & 0.11 & $0.11^{*}$ & $-0.22 * *$ \\
\hline Katsina & 1918-12 & 0.09 & 0.09 & $-0.32 * *$ & $-0.32 * *$ & $0.50 * *$ & $0.50 * *$ & $-0.29 * *$ & $-0.29 * *$ & $-0.36^{* *}$ \\
\hline Yelwa & 1926-12 & 0.07 & 0.25 & $-0.39 * *$ & $-0.40 * *$ & -0.17 & -0.17 & 0.02 & 0.01 & $--0.21 * *$ \\
\hline Yola & 1914-12 & 0.10 & 0.06 & -0.08 & -0.20 & $-0.26^{*}$ & $0.31 *$ & $-0.12 *$ & $-0.20 *$ & 0.02 \\
\hline Bauchi & $1908-12$ & -0.10 & -0.10 & $-0.27 *$ & $-0.27^{*}$ & 0.14 & 0.15 & -0.06 & -0.06 & $-0.25 * *$ \\
\hline Gusau & $1953-12$ & NA & NA & $-0.30 *$ & $-0.31 * *$ & -0.14 & -0.14 & -0.05 & -0.05 & $-0.23 * *$ \\
\hline Maidug & $1915-12$ & $0.25 *$ & $0.24 *$ & $-0.28 *$ & $-0.28 *$ & $0.26^{*}$ & $0.26 *$ & -0.07 & -0.07 & $-0.27 * *$ \\
\hline Nguru & $1942-12$ & 0.06 & 0.04 & $-0.49 * *$ & $-0.50 * *$ & 0.20 & 0.20 & $-0.28 * *$ & $-0.28^{* *}$ & $-0.46^{* *}$ \\
\hline Kaduna & $1930-12$ & -0.04 & -0.04 & -0.20 & -0.18 & -0.07 & -0.03 & $-0.13^{*}$ & -0.11 & -0.15 \\
\hline Zaria & 1943-12 & 0.02 & 0.02 & $-0.25^{*}$ & $-0.27 *$ & 0.06 & 0.10 & -0.04 & -0.03 & $-0.22 * *$ \\
\hline Minna & 1916-12 & -0.03 & -0.03 & $-0.26^{*}$ & $-0.23 *$ & 0.04 & 0.08 & $-0.17 * *$ & $-0.14 *$ & $-0.30 * *$ \\
\hline Bida & 1928-12 & -0.20 & -0.17 & -0.17 & -0.19 & 0.05 & 0.11 & $-0.18 * *$ & -0.11 & $-0.25^{* *}$ \\
\hline Jos & $1922-12$ & 0.03 & 0.06 & -0.20 & -0.20 & $0.31 *$ & $0.31 *$ & $-0.23 * *$ & $-0.20 * *$ & -0.07 \\
\hline Lokoja & 1916-12 & 0.13 & 0.14 & -0.08 & -0.12 & -0.02 & 0.01 & 0.05 & 0.09 & 0.00 \\
\hline Makurd & $1927-12$ & -0.15 & -0.16 & $-0.33 * *$ & $-0.31 * *$ & 0.00 & -0.00 & $-0.25^{* *}$ & $-0.21^{* *}$ & 0.03 \\
\hline Ilorin & 1916-12 & $0.21 *$ & $0.22 *$ & -0.15 & -0.16 & 0.00 & -0.01 & -0.11 & -0.06 & $-0.33 * *$ \\
\hline Lagos & $1904-12$ & 0.08 & 0.04 & -0.19 & -0.14 & -0.05 & -0.10 & -0.08 & -0.03 & $-0.19 *$ \\
\hline Ibadan & $1905-12$ & 0.03 & -0.01 & -0.05 & 0.03 & $0.28 *$ & $0.28 *$ & $0.11 *$ & $0.15^{*}$ & $-0.25^{* *}$ \\
\hline Ondo & 1906-12 & -0.18 & -0.09 & -0.01 & 0.07 & -0.01 & -0.20 & $0.15 * *$ & $0.19 * *$ & 0.13 \\
\hline Oshog & $1935-12$ & $0.31 *$ & $0.30 *$ & -0.01 & 0.05 & 0.09 & -0.39 & $0.25 * *$ & $0.27 * *$ & 0.09 \\
\hline Benin & 1906-12 & 0.17 & 0.16 & -0.17 & -0.18 & $0.30 *$ & 0.13 & $0.20 * *$ & $0.18^{* *}$ & 0.10 \\
\hline Warri & 1908-12 & $0.26^{*}$ & $0.26^{*}$ & -0.12 & -0.19 & -0.25 & -0.25 & 0.02 & 0.02 & 0.06 \\
\hline Port & 1903-12 & $-0.33^{* *}$ & $-0.29 *$ & $-0.23^{*}$ & -0.22 & 0.04 & -0.02 & $-0.41 * *$ & $-0.36^{* *}$ & 0.01 \\
\hline Enugu & 1916-12 & -0.17 & -0.14 & -0.07 & 0.05 & -0.05 & -0.00 & -0.05 & 0.06 & 0.06 \\
\hline Calaba & $1903-12$ & 0.01 & 0.07 & -0.09 & 0.01 & 0.11 & 0.08 & -0.09 & -0.03 & 0.11 \\
\hline Ikom & $1972-12$ & NA & NA & -0.18 & -0.15 & 0.21 & 0.20 & 0.02 & 0.07 & 0.12 \\
\hline
\end{tabular}

The mean annual rainfall for each of the stations was derived for three different sub-periods and its departure from the long-term mean was generated for the respective stations. The rainfall departures for the sub-periods 1931-60, 1961-90 and 1991-2012 were represented in maps to show its spatial patterns (see Figure 5a-c). Figure 5a showed that with the exception of localized cases of negative departures, most parts of the country had positive rainfall patterns in the 1931-1960 period. This suggests that during the period 1931-1960, the ITD might have moved further north and therefore residential time of the rain-bearing maritime air mass was longer than normal in the far north during the period. In such a situation, the whole country will be under the influence of the maritime air mass producing a wetter than normal condition as speculated by Olaniran (1991). This could have resulted to the pattern observed in Figure 5a. Figure 5b showed that 
nearly the whole country had negative rainfall patterns in the 1961-90 period. This coincides with the droughts of the 1970s and 1980s in the West African Sahel. The intensity of the West African monsoon might have been suppressed during this period due to warmer than normal sea surface temperatures over the Atlantic Ocean. This could weaken the monsoonal flux into west and central Africa and consequently reduce rainfall in the region as discussed by Le Barbe $e t$ al., 2001. Figure 5c revealed that most areas had positive rainfall pattern in 1991-2012 period including Sokoto, Kano and Maiduguri stations all located in the Sudano-Sahelian region of the country. This supports the hypothesis of the apparent rainfall recovery in the Sahel after the droughts of the 1982-1987 in the region as reported by (Nicholson, 2005).

Nicholson (2005) examined the question of "recovery" of the rains in West African Sahel using seasonal and August rainfall time series over the period 1998-2003 for eight zones, within latitude $12^{0} \mathrm{~N}$ to $20^{\circ} \mathrm{N}$ and showed that, in the three zones to the south, seasonal totals exceeded the long-term means in all years and conditions were comparable to or wetter than those during the wet decade of the 1950s. The wettest years were 1998, 1999 and 2003.

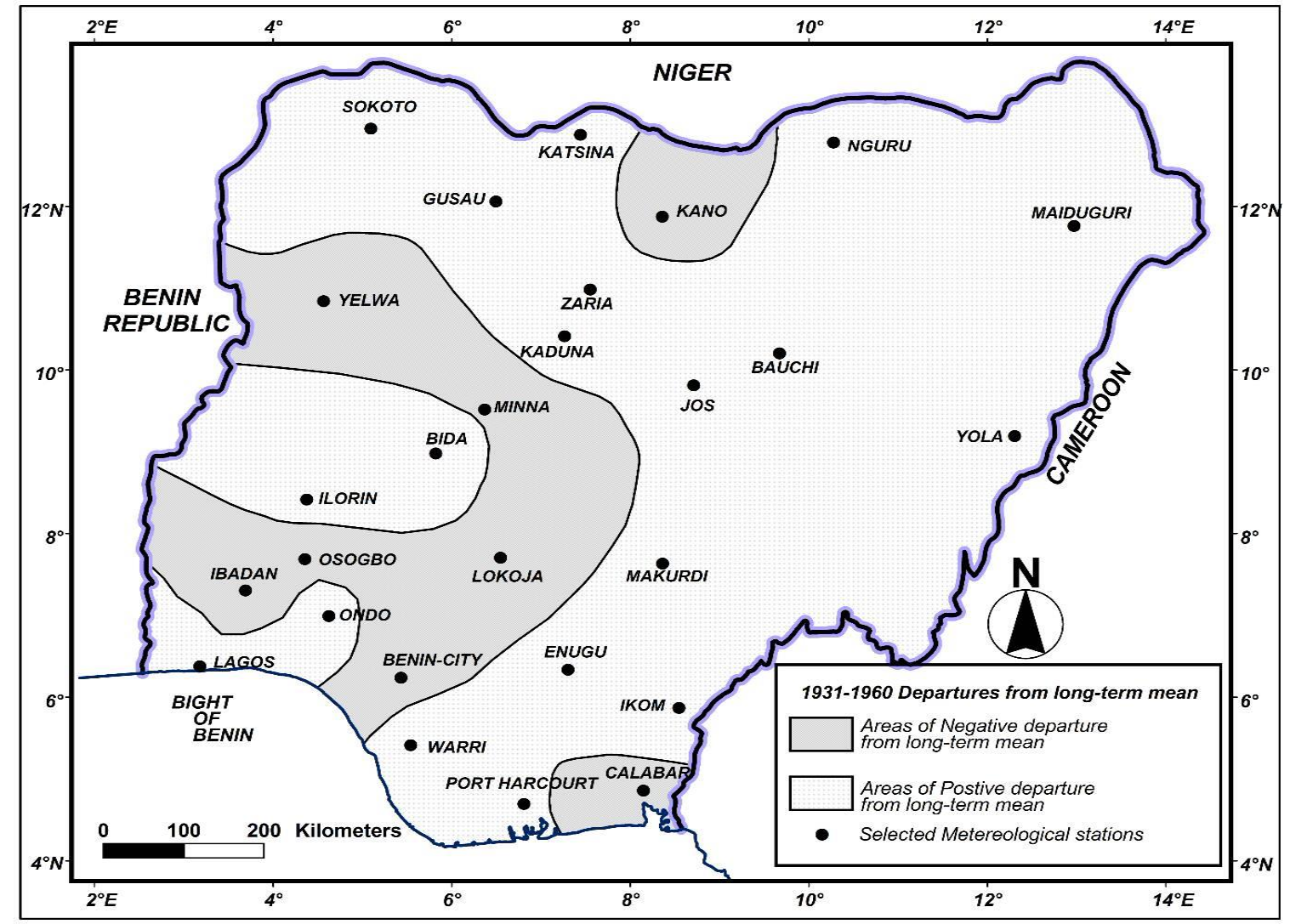

Figure 5a: Spatial Patterns of Mean Annual Rainfall Departures from the Long-Term Mean for the 1931-60 sub-Climatological Period in Nigeria Source: Authors' Compilation, 2018 


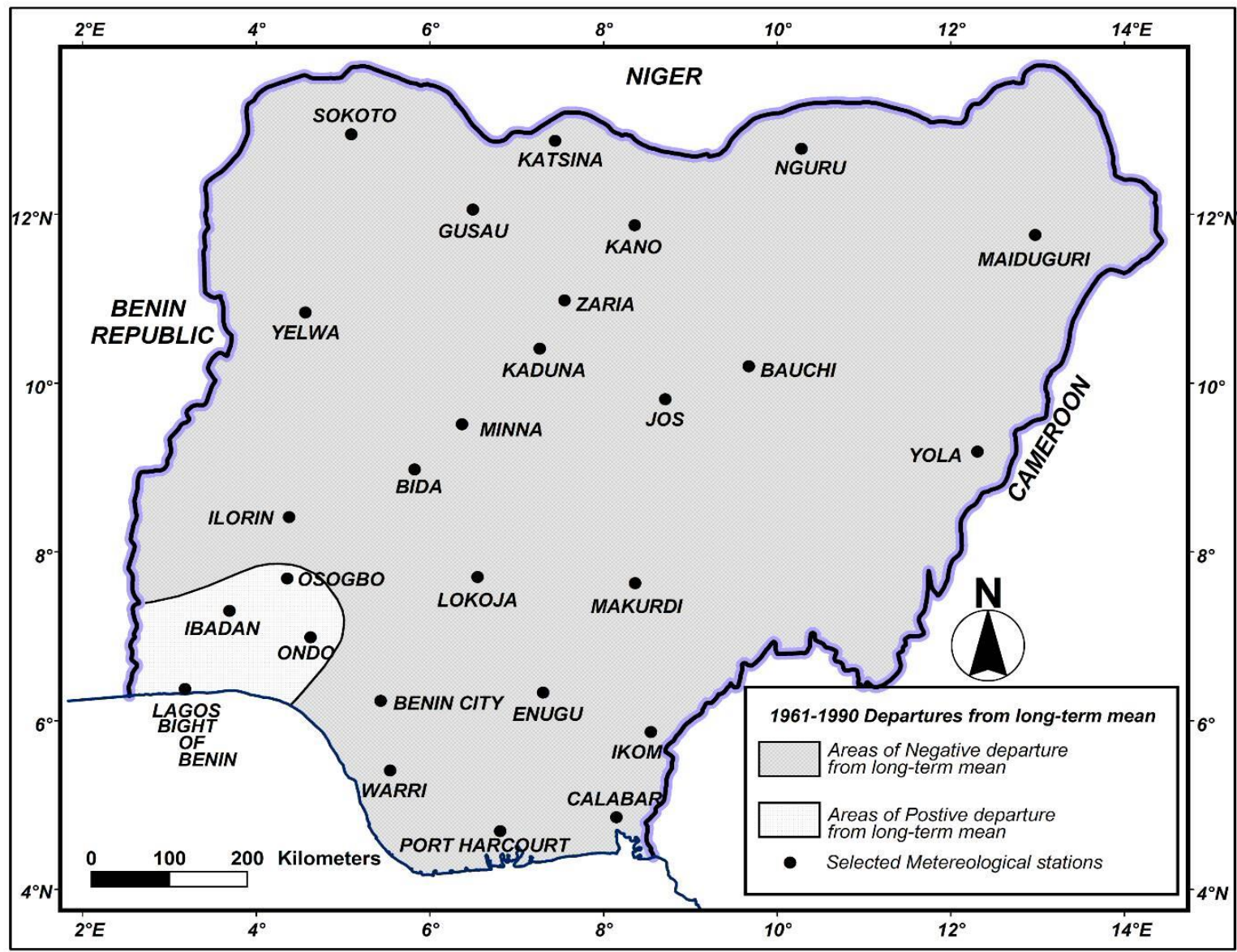

Figure 5b: Spatial Patterns of Mean Annual Rainfall Departures from the Long-Term Mean for the 1961-90 Sub-Climatological Periods in Nigeria Source: Authors' Compilation, 2018

In a related study, Umar (2013) examined the annual rainfall anomalies in the north, middle belt, south-west and southeastern regions of Nigeria using the annual rainfall series of the 27 Nigerian meteorological stations over the period 19012000. The stations considered in the present study were same with those used by Umar and only differed in their respective lengths of records. The rainfall anomaly patterns depicted by zones in the Umar's study were to some extent comparable with the observed changing patterns in rainfall over Nigeria as depicted in the present study (see Figure 6).

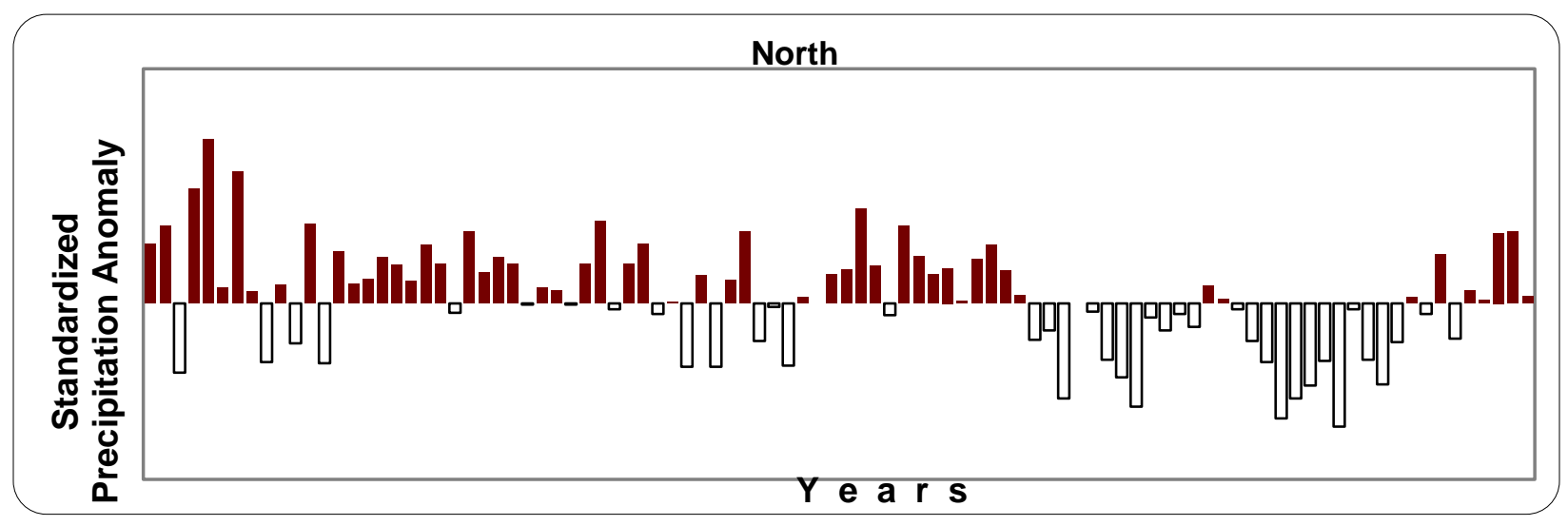



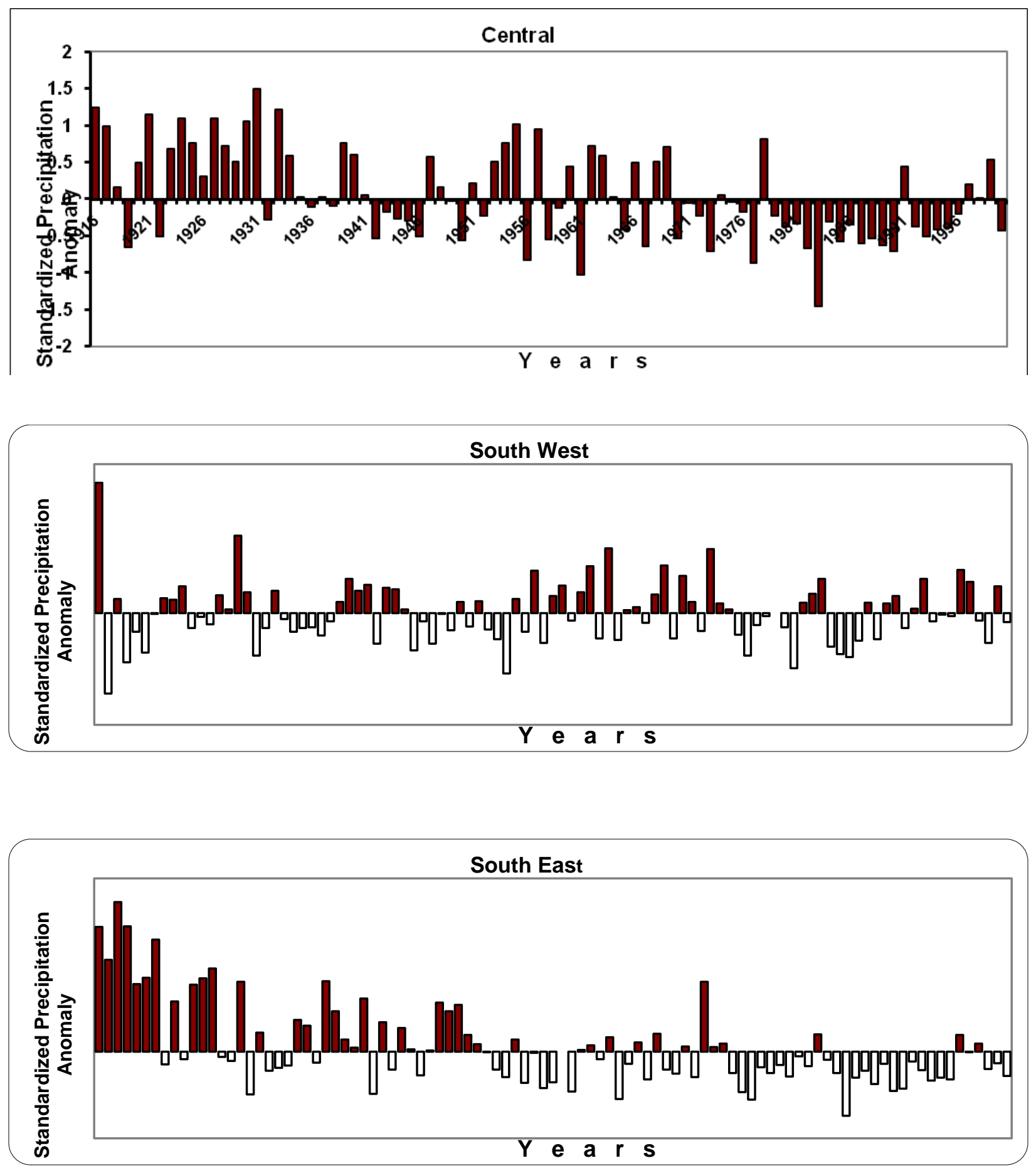

It could be observed from Figure 6 that the wet period of the 1950s was observed in virtually all the regions except southeastern region which experienced a pronounced drought throughout the 1950s. Similarly, a relatively wet period was observed in the 1930s in all the regions except the middle belt. Such isolated cases could be attributed to the irregularities in the south-north movements of the ITD as widely reported in the literature (Olaniran, 1991, 2005; Oladipo, 1995; Adelekan, 1998; Odekunle, 2004, 2010; Udjugo, 2005). A closed examination of Figure 6 also revealed that a below 
average rainfall prevailed throughout the 1968-76 and 1983-87 in country which is in conformity with the pattern depicted in Figure $5 b$ of the present study.

\section{EL NINO-SOUTHERN OSCILLATION (ENSO) AND RAINFALL PATTERNS IN NIGERIA}

It could be observed from Table 2 that the North Atlantic SSTs accounts for $12.0 \%$ of the explained variance in rainfall anomalies for the northern region while South Atlantic SSTs accounts for $12.4 \%$ of the explained variance in rainfall anomalies in the middle belt and central region of Nigeria. However, none of the predictors considered could explain the variance in rainfall anomalies for the South-West and South-East region of Nigeria over the period 1951-2000. Lack of significant correlation between annual rainfall anomalies for the south-west and anomaly indices of SSTs and ENSO could be as result of the effects of the spatial averages and such correlations could have been masked due to the averaging effects. The same reason could be responsible for similar situation observed in the south-eastern region of Nigeria.

Table 2: Summary of the Regression between Annual Rainfall Anomalies and Anomaly Indices of SST and ENSO in Nigeria.

\begin{tabular}{lllll}
\hline Country/Region & Variable(s) & $\mathrm{R}$ & $\mathrm{R}^{2}$ & Significance \\
\hline North & South Atlantic SSTA & 0.35 & 0.120 & 0.01 \\
Central & North Atlantic SSTA & 0.35 & 0.124 & 0.01 \\
South-West & - & - & - & - \\
South-East & - & - & - & - \\
\hline
\end{tabular}

Source: Authors' Computation, (2017)

Table 3 shows that the North, Middle belt and South-West had 12.7\%, 10.2\% and 08.0\% of the explained variance in growing season rainfall totals anomalies accounted for by the South Atlantic SSTs, North Atlantic SSTs and South Atlantic SSTs anomalies respectively.

Table 3: Summary of the regression between growing season rainfall anomalies and anomaly indices of SST and ENSO in Nigeria

\begin{tabular}{lllll}
\hline Country/Region & Variable(s) & $\mathrm{R}$ & $\mathrm{R}^{2}$ & Significance \\
\hline North & South Atlantic SSTA & 0.356 & 0.127 & 0.01 \\
Central & North Atlantic SSTA & 0.319 & 0.102 & 0.01 \\
South-West & South Atlantic SSTA & 0.282 & 0.080 & 0.01 \\
South-East & - & - & - & - \\
\hline
\end{tabular}


The growing season rainfall anomalies of the South-Eastern region of Nigeria were not influenced by any of the predictors considered in this study which could as well be attributed to the averaging effects. The relationship between Nigerian rainfall and the couple ocean-atmospheric phenomena of El Nino/Southern Oscillation (ENSO) and Sea Surface Temperature (SSTs) is also investigated using five selected stations located in the soudano-sahelian region of Nigeria which include Katsina, Nguru, Maiduguri, Kano and Sokoto. The annual rainfall series for each of the stations is utilized for a 50-year period (1951-2000). A composite of (June +July+August) rainfall is also derived for each station within the same period (1951-2000). The annual and composite rainfall series for these stations comprised the actual values of rainfall (i.e. non-normalized). Both series are then subjected to step wise multiple regression in an attempt to evaluate the nature of the relationship between rainfall in the Sudano-Sahelian region of Nigeria and indices of Sea Surface Temperature (SSTs) and El-Nino/Southern Oscillation (ENSO). Annual rainfall anomalies at five Sudano-Sahelian stations including Katsina, Nguru, Maiduguri, Kano and Sokoto were related to East-Central Pacific SSTs $\left(r^{2}=0.44\right.$, $\mathrm{p}<0.001)$, Global SSTs $\left(\mathrm{r}^{2}=0.37, \mathrm{p}<0.001\right)$, North Atlantic SSTs $\left(\mathrm{r}^{2}=0.29, \mathrm{p}<0.001\right)$, North Atlantic SSTs $\left(\mathrm{r}^{2}=0.21\right.$, $\mathrm{p}<0.001)$ and South Atlantic SSTs $\left(\mathrm{r}^{2}=0.16, \mathrm{p}<0.05\right)$ respectively (Table 5).

Table 4: Summary of the regression of Annual Rainfall on SSTs and ENSO Indices at the Selected Sudano-Sahelian Stations of Nigeria

\begin{tabular}{ccccc}
\hline Station & Variable(s) & $\mathrm{R}$ & $\mathrm{R}^{2}$ & Significance \\
\hline Katsina & Global SST & 0.45 & 0.198 & 0.00 \\
& North Atlantic SST & 0.60 & 0.359 & 0.00 \\
& NINO 3.4 SST & 0.67 & 0.442 & 0.00 \\
& & & \\
Nguru & South Atlantic SST & 0.52 & 0.274 & 0.00 \\
& Global SST & 0.61 & 0.366 & 0.00 \\
Maiduguri & Global SST & 0.36 & 0.129 & 0.01 \\
& North Atlantic SST & 0.54 & 0.288 & 0.00 \\
Kano & North Atlantic SST & 0.46 & 0.207 & 0.00 \\
Sokoto & South Atlantic SST & 0.40 & 0.160 & 0.00 \\
\hline
\end{tabular}

Source: Authors' computation, 2018

The growing season rainfall anomalies for Katsina, Nguru, Maiduguri, Kano and Sokoto were caused by East-Central Pacific SSTs $\left(r^{2}=0.44, p<0.00\right)$, Global SSTs $\left(r^{2}=0.37, p<0.00\right)$, ENSO index $\left(r^{2}=0.22, p<0.00\right)$, North Atlantic SSTs $\left(r^{2}=0.21, p<0.00\right)$ and South Atlantic SSTs $\left({ }^{r} 2=0.15, \mathrm{p}<0.00\right)$ respectively (see Table 6). 
Table 5: Summary of the Correlation of Growing Season Rainfall on SSTs and ENSO Indices at the Selected Sudano-Sahelian Stations of Nigeria

\begin{tabular}{lllll}
\hline Station & Variable (s) & $\mathrm{R}$ & $\mathrm{R}^{2}$ & Significance \\
\hline Katsina & Global SST & 0.44 & 0.189 & 0.00 \\
& North Atlantic SST & 0.54 & 0.290 & 0.00 \\
& NINO 3.4 SST & 0.64 & 0.408 & 0.00 \\
\multirow{2}{*}{ Nguru } & South Atlantic SST & 0.54 & 0.294 & 0.00 \\
& Global SST & 0.61 & 0.377 & 0.00 \\
\multirow{2}{*}{ Maiduguri } & South Atlantic SST & 0.35 & 0.121 & 0.01 \\
& ENSO Index & 0.47 & 0.218 & 0.00 \\
Kano & North Atlantic SST & 0.46 & 0.207 & 0.00 \\
Sokoto & South Atlantic SST & 0.39 & 0.151 & 0.01 \\
\hline
\end{tabular}

The foregoing result implies that extra ordinary warming of sea surface temperatures (SSTs) over the Atlantic and Pacific oceans is significantly related to the observed inter-annual variability of rainfall in Sudano-Sahelian region of Nigeria. Such extra ordinary warming was found to significantly reduce the meridional gradient of SST south of the Inter-Tropical Discontinuity or (ITD) in dry years, and a as result, leads to a weakened Hadley meridional circulation. The weakened circulation reduces the intensity of the south-west monsoon flow into West and central Africa and consequently reduces rainfall in the region as discussed by several other scholars (Folland et al., 1986; Druyan, 1991; Dai and Wigley, 2000; Nicholson, 1981; Nicholson and Kim, 1997; Nicholson and Kone, 2000; Rowell, 2000; Nicholson and Grist, 2001; Le Barbe et al., 2002; Reason and Landman, 2006; Nicholson and Webster, 2007). The colder than normal SSTs during wet years is associated with strong Hardley Circulation and massive moisture flux into central and western Africa and hence, enhanced rainfall in the region (Nicholson and Selato, 2000).

It is evidently clear from the results of the correlations among rainfall, Sea Surface temperatures (SSTs) and El Nino/Southern Oscillation (ENSO) presented in this study that, SSTs variables rather than ENSO event are more significant to Nigerian rainfall in terms of inter-annual and intra-seasonal rainfall fluctuations in the country. Similar findings have been reported in other parts of African Sahel (Semazzi et al., 1988; Olaniran, 1991, 2005; Nicholson and Kim, 1997; Odekunle, 2004, 2010; Odekunle and Eludoyin, 2008; Munemoto and Tachibana, 2012)

\section{CONCLUSION}

The study examined the relationship of El Nino/Southern Oscillation (ENSO) to rainfall patterns in Nigeria. The annual rainfall totals, growing season rainfall and annual raindays data of 27 selected Nigerian meteorological stations with varying lengths of records over the period 1903-2012 were analyzed for trends. The annual rainfall totals, growing season rainfall and annual raindays exhibited a significant downward trend at most of the stations over the period of the study. 
Annual rainfall pattern in the country had changed from a positive pattern within the 1931-60 period to a negative pattern in the 1961-1990 period and to a positive pattern in the 1991-2012. The SSTs anomalies over the Atlantic and Pacific Oceans were found to have significant roles in the observed changing patterns of rainfall in Nigeria. The ENSO was found to be insignificant in inter-annual rainfall variability over Nigeria as it only affected the rainfall perturbations at Maiduguri, a station located in the Sahelian region of Nigeria. It is feared that if the trend persists, severe droughts may occur within 2021-2050 with concomitant effects on the socio-economic sectors of the country. The paper therefore concludes that the sea surface temperatures (SSTs) over the Atlantic and Pacific oceans should be incorporated into the seasonal rainfall prediction model for accurate prediction of the extreme rainfall anomalies ahead of the rainy season in order to enable farmers to plan for their farming activities in Nigeria.

\section{ACKNOWLEDGMENT}

The authors greatly appreciate the assistance rendered by the Nigerian Meteorological Agency, Lagos in the course of collecting rainfall and raindays data used for this study. We also appreciate the Climatic Prediction Centre (CPC) for allowing us to download and use its published anomaly data of Sea Surface Temperatures (SSTs) and Southern Oscillation Index (SOI). We will not fail to appreciate the assistance rendered by Mr. A. Joseph, a cartographer in the Department of Geography, University of Ibadan, and Dr. N. B. Nathaniel, a GIS expert in the Department of Geography, Usmanu Danfodiyo University, Sokoto, who individually assisted in preparing the maps and other illustrations used in this paper. 


\section{REFERENCES}

Adefolalu, D. O. (1986). Rainfall trends in Nigeria. Theory and Applied Climatology 37(4): 23-26

Adelekan, I. O. (1998). Spatio-temporal variations in thunderstorm rainfall over Nigeria, International Journal of Climatology 18: 1273-1284.

Ati, O. F, Iguisi, E. O, Muhammad, S. O (2010). Effects of El Niño/Southern Oscillation in Katsina, Nigeria. The African Journal of Agricultural Resource, 5 (23): 3278-3278. https://doi:10.5897/AJAR08.455

Ayoade, J. O., (2008). Techniques in Climatology. Stirling-Horden Publishers. Ibadan.

Ayoade, J. O. (2011). Introduction to Climatology for the tropics, $2^{\text {nd }}$ edition, Spectrum Books

Limited, Ibadan.

Battisti, D. S. and Hirst, A. C. (1989). Inter-annual variability in a tropical atmosphere-ocean model: influence of the basic state, ocean geometry and non-linearity. Journal of Atmospheric Science 46: 1687-1712.

Benard, T. T. (2000), The Influence of ENSO and North Atlantic Sea Surface Temperature Anomaly on Extreme Rainfall Events in Makurdi, Nigeria. Journal of Meteorology and Climate Science, 7: 28-33.

Dai, A. and Wigley, T. M. L. (2000). Global Patterns of ENSO-induced Precipitation Geophysical Research Letters, 27.9: 1283-1286.

Druyan, M. (1991). The sensitivity of Sub-Saharan Precipitation to Atlantic SST. Journal of Climate 18: 17-36.

Druyan, L. M. (2011). Studies of the $21^{\text {st }}$-century precipitation trends over West Africa during the years 1950-90. Journal of Climate 15: 187-202.

Folland, C.K., Palmer, T. N. and Parker, D. E. (1986). Sahel Rainfall and World-Wide Sea Surface Temperatures. Nature 320: $602-607$.

Halpert, M. S. and Popelewski, C. F. (1992). Surface temperature patterns associated with the Southern Oscillation. Journal of Climate 5: 577-593.

Hamilton, K. and Allingham, A. M. (1988). A note on equatorial Atlantic sea surface temperature variations, 1890-1979. Oceanography 26: 666-678.

Jin, F. F. and Neelin, J. D. (1993). Modes of Inter-Annual Tropical Ocean-Atmosphere Interaction- A unified view. Part 1: Numerical results. Journal of Atmospheric Science 50: 811-829.

Kendall, M. G. and Stuart, A., (1961). The advanced theory of statistics. Hafner Publishing Company. NewYork. U SA.

Landsea, C. W. and Knaff, J. A. (2000). How much skill was there in forecasting the very strong 1997-98 El Niño? Bull American. Meteorological. Society. 81: 2107-2119.

Mohit, D. (2014). El niño, la niño and their effects. Retrieved January 30, 2018 from www.simplydecoded.com/2014/07/20/el nino-lanino-effects/

Munemoto, M. and Tachibana, Y. (2012). The recent trend of increasing precipitation in Sahel and the associated inter- 
hemispheric dipole of global SST. International Journal of Climatology 32.1346-1353.

Nicholson, S. E. (1981). Rainfall and atmospheric circulation during drought period and wetter years in West Africa. Monthly Weather Review 109: 2191-2208.

Nicholson, S. E., B. Some, and B. Kone, (2000). An analysis on recent rainfall conditions in West Africa, including the rainy season of the 1997 ENSO year. Journal of. Climate, 13, 2628-2640.

Nicholson, S. E. and Selato, J. C. (2000). The influence of La-Nina on African rainfall. International Journal of Climatology, Vol. 20, 1761-1776.

Nicholson, S. E. (2005). On the question of the "recovery" of the rains in the West African Sahel. Journal of Arid Environment, 63: p. 615-641.

Nicholson, S. E. (2013). The West African Sahel: A review of recent studies on the rainfall regime and its inter-annual variability. ISRN Meteorology 20: 1-32.

Nicholson, S.E and Kim, J. (1997). The relationship of the El-nino/Southern Oscillation to African rainfall. International Journal of Climatology 17.2: 117-135.

Nicholson, S. E. and Grist, J. P. (2001). A conceptual model for understanding rainfall variability in the West African Sahel on inter-annual and inter-decadal timescales. International Journal of Climatology 21:1733-1757.

Nicholson, S. E. and Webster, P. J. (2007). A physical basis for the inter-annual variability of rainfall in the Sahel. Quarterly Journal of the Royal Meteorological Society 133: 2065-2084.

Nnawuike, N. E. (2016). Assessment of the impact of El Niño- Southern Oscillation (ENSO) Events on Rainfall Amount in South-western Nigeria. Journal of physical Science and Environmental Studies, 2 (2): 23-29

Odekunle, T. O. and Eludoyin, A. O. (2008). Sea surface temperature patterns in the Gulf of Guinea: their implications for the spatio-temporal variability of precipitation in West Africa. International Journal of Climatology 28: 1507-1517.

Odekunle, T.O. (2004). Rainfall and the length of the growing season in Nigeria. International Journal of Climatology 24: 1124-1133.

Odekunle, T. O. (2010). The influence of the inter-tropical discontinuity (ITD) on rainfall Characteristics over Nigeria. Geographical Research Letters 4: 218-234

Oladipo, E. O. 1995. Some statistical characteristic of drought area variations in the savanna region of Nigeria. Theoretical and Applied Climatology 50: 143-155.

Olaniran, O. J., (1986). On classification of tropical climates for a study of regional climatology: Nigeria as a case study. Geografiska Annalar 68a. 4: p. 543-555.

Olaniran, J. O. (1991). Rainfall anomaly patterns in five wet and dry years over Nigeria. International Journal of Climatology, 8: 542-559

Olaniran, O. J. (2005). Rainfall anomalies in Nigeria: Contemporary understanding. Inaugural Lecture delivered at the 
University of Ilorin, Nigeria. 51Pp.

Palmer, T.W. (1986). Influence of the Atlantic, Pacific and Indian oceans on Sahel rainfall. Nature 322: 251-253.

Pidwirny, M. (2006). El Niño, La Niña and the Southern Oscillation Fundamentals of physical Geography, $2^{\text {nd }}$ Edition. Accessed October 22, 2009

Popelewiski, C.F. and Halpert, M.S., (1987). Global and regional scale precipitation patterns associated with the Elnino/Southern Oscillation. Monthly Weather Review 115: 1606-1626. Royal Meteorology Society, 127: 16831706.

Reason, C. J. C., Landman, W. A. and Tenant, W., (2006). Seasonal to decadal prediction of the southern Africa climate and its links with the variability of the Atlantic Ocean. Bulletin of the American Meteorological Society 87: 941-955.

Rowell, D. P. 2001. Teleconnections between the tropical Pacific and the Sahel. Q. Journal of Royal Meteorology Soc. 127: 1683-1706.

Salau, O. R, Fasuba, A; Aduloju, K. A; Adesakin, G. E; Fatigun, A. T. (2016) Effects of Changes is Seasonal Mean Temperature and Rainfall in Nigeria. Journal of Climate, 4 (1): 5, https:// doi: 10.3390

Semazzi, F. H. M., Mehta, V. and Sud, Y. C. (1988). An investigation of the relationship between sub-Saharan rainfall and global sea surface temperatures. Ocean-Atmosphere 26.1: 118-138.

Shehu, A. U, Yelwa, S. A, Sawa, B. A and Adegbehin, A. B. (2016). The Influence of El Niño Southern Oscillation (ENSO) Phenomenon on Rainfall Variation Kaduna Metropolis, Nigeria. Journal of Geography, Environmental and Earth Science International, 8 (1): 1-9

Suarez, M. J. and Schopf, P. S. (1988). A delayed action oscillator for ENSO. Journal of Atmospheric Science 45: 32833287.

Udjugo, P. O. A., (2005). An Analysis of rainfall pattern in Nigeria. Global Journal of Environmental Sciences, 4.2: 139-145.

Umar, A. T. 2013. Frequency and spatial patterns of drought in Nigeria. Journal of Meteorology and Climate Science, 11 1: 58-74.

Walker, G. T. and Bliss, E. W. (1932). World Weather v. Royal Meteorological Society 4: 53-84. Webster, P. J. and Yang, M. 1992. Monsoons: Processes, predictability and the prospects for prediction. J. Geophysical Research 103: $14451-14510$.

WHO (World Health Organization, 2015) El Niño Southern Oscillation (ENSO) and Health, updated November 1, 2015. 